\title{
The impact of social capital and social support on the health of female-headed households: a systematic review
}

\author{
Somayyeh Khazaeian ${ }^{1}$, Nourossadat Kariman ${ }^{2}$, Abbas Ebadi ${ }^{3}$, Malihe Nasiri ${ }^{4}$
}

1 Ph.D. Candidate of Reproductive Health, Student Research Committee, Department of Midwifery and Reproductive Health, School of Nursing \& Midwifery, Shahid Beheshti University of Medical Sciences, Tehran, Iran

${ }^{2}$ Ph.D. of Reproductive Health, Assistant Professor, Midwifery and Reproductive Health Research Center, School of Nursing \& Midwifery, Shahid Beheshti University of Medical Sciences, Tehran, Iran

${ }^{3}$ Ph.D. in Nursing, Professor, Behavioral Sciences Research Center, School of Nursing, Baqiyatallah University of Medical Sciences, Tehran, Iran

${ }^{4} \mathrm{Ph} . \mathrm{D}$. in Biostatistics, Assistant Professor, School of Nursing \& Midwifery, Shahid Beheshti University of Medical Sciences, Tehran, Iran

Type of article: Systematic review

\begin{abstract}
Background and aim: Social capital and social support as determinants of health play an important role in the health of female heads of households. Considering the increasing number of female-headed families in Iran and the world, this study was conducted to systematically review the impact of social capital and social support on the health of female heads of households.

Methods: This study was conducted as a systematic review in September 2016. Its data were collected from available papers in different databases including Iranmedex, Magiran, Scientific Information Database (SID), Irandoc, Scopus, Science Direct, PubMed and Google Scholar. Using advanced search, all published papers from 2000 to 2015 with full text were selected using related keywords. After reviewing by browsers and adapting to the inclusion and exclusion criteria, 15 papers were entered into the study. The Strengthening the Reporting of Observational Studies in epidemiology (STROBE) checklist was used to evaluate the quality of papers.

Results: Based on the findings of these studies, there was a significant relationship between social capital and its components (trust, sense of belonging and social participation) as well as all aspects of health. Additionally, social support and its dimensions (emotional, instrumental and informational) affected health; however, among these dimensions, instrumental support of a stronger predictor was concerned with health, especially mental health.

Conclusion: Social factors such as social capital and social support are effective on human health, particularly health of female-headed households, since they affect proactive identity and increase information resources, collaboration as well as collective decisions and actions. Furthermore, they provide emotional and instrumental support to group members and prevent further health problems.
\end{abstract}

Keywords: Head of household, Female, Social capital, Social support, Health

\section{Introduction}

Changes in societies over recent decades have led to changes in family structure and this has imposed the responsibility of managing life and tolerating higher levels of stresses for female heads of households (1). Factors such as death, addiction, disability of husband and abandonment by immigrant men or imprudence make this group

\section{Corresponding author:}

Assistant Professor Dr. Nourossadat Kariman, Department of Midwifery and Reproductive Health, School of Nursing and Midwifery, Shahid Beheshti University of Medical Sciences, Tehran, Iran.

Tel:+98.2188202512, Fax:+98.2188202512,Email: n_kariman@yahoo.com, and n_kariman@sbmu.ac.ir

Received: April 20, 2017, Accepted: September 06, 2017, Published: December $201 \overline{7}$

iThenticate screening: September 03, 2017, English editing: December 10, 2017, Quality control: December 15, 2017

This article has been reviewed / commented by three experts

(C) 2017 The Authors. This is an open access article under the terms of the Creative Commons Attribution-NonCommercialNoDerivs License, which permits use and distribution in any medium, provided the original work is properly cited, the use is non-commercial and no modifications or adaptations are made. 
highly vulnerable (2). Sudden transition of responsibility from man to woman creates a series of insecurities and additional duties such as loss of income, raising children and playing a dual role (the role of father and mother) for this group of women and in addition to its adverse effects on physical and mental health and life satisfaction, it causes new psychological problems for them (3). In Iran, statistical data reveal the increasing trend of the number and proportion of these women in the last decade. According to the population and housing census conducted in 2011, the number of female-heads of families is more than two million five hundred and sixty-three thousand. In fact, in 2011, the share of female heads of households was 12.1 percent, showing a significant growth compared to other periods (4). Today, a considerable part of medical sociology and public health studies is dedicated to healthrelated issues (5). Most studies emphasize social capital and social support as two major social determinants affecting health (6). In fact, the concept of health is associated with these two factors and today, many physical and mental disorders are strongly related to these two social determinants. Therefore, these factors should be taken into account during setting health improvement policies $(7,8)$. The World Bank defines social capital as the entire norms and networks facilitating the collective action (9) and being composed of components such as membership in social groups, participation in collective actions, social cohesion and trust, as well as information and communication (10). Social support is a multidimensional structure being hard to define. This structure reveals individuals' perception of being protected, loved and valuable (11). Belonging to communication networks and mutual commitments to each other are two characteristics of social support (12). Social support is generally divided into two aspects: structural and functional. The structural aspect of social support generally refers to the size and source of social network and presence of people to help each other, and functional aspect refers to certain functions such as emotional, material and informational functions that supportive people can provide for others (13). In recent years, international organizations and institutions active in the area of development have referred to female-heads of families as the poorest of the poor; this is while, the World Health Organization considers women's health as one of the indicators of development in the process of evaluation of countries (14). In this regard, female heads of households, owing to their dual role in the family and numerous evidence confirming their deprivation due to gender and their subsequent deprivation of resources, are at risk of more serious damages (15). Identification and evaluation of social determinants associated with female heads of households in each community seems necessary and important, since such people due to massive responsibilities, lack of socio-economic support, lack of access to good jobs and lack of skills may experience social isolation and lack of access to social networks $(16,17)$. In addition, the key role of social factors in describing inequalities in this group through focusing attentions on facts and important phenomena, may facilitate economic growth by highlighting the importance of participation and trust in female heads of households (18). Based on the issues raised and considering the importance of social factors such as social capital and social support affecting the health of female heads of households, the present study reviews papers investigating the impact of social capital and social support on the health of female heads of households.

\section{Material and Methods}

\subsection{Research Design and Search Strategy}

This was a systematic review study conducted in September 2016. It studied the impact of social capital and social support and their role on the health of female heads of households in Iran and the world. Results were analyzed based on studies conducted in national and international journals provided in databases such as Iranmedex, Magiran, Scientific Information Database (SID), Irandoc, Scopus, Science Direct, PubMed and Google Scholar. Search keywords included health, female heads of households, social capital, migrant women, single women, social support, single-parent, single and married mothers, health, quality of life and social capital that were searched using operators of "AND" and "OR".

\subsection{Inclusion and Exclusion Criteria}

Inclusion criteria included the following: 1. Studies conducted on the health of female-headed households; 2. Descriptive-analytical studies; 3. Studies with full-text and 4. Papers published from 2000 to 2015, while exclusion criteria comprised the following 1. Irrelevant papers; 2. Data on review papers, case reports, abstracts, posters and letters to editors; 3. Repetitious papers and 4. Case-control studies..

\subsection{Quality Assessment}

This study was conducted in several phases, including accurate determination of issue, collection, analysis and interpretation of findings according to Preferred Reporting Items for Systematic Reviews and Meta-Analyses (PRISMA). After reviewing by browsers and according to inclusion and exclusion criteria, the Strengthening the Reporting of Observational Studies in epidemiology (STROBE) checklist was used to evaluate the quality of the papers. This checklist contained 22 parts, including title, abstract, introduction, method of work, type of study, data 
retrieval tool, statistical analysis, goals, results, discussion and conclusion. Scoring was conducted based on the importance of each part according to the present study. Studies that were scored at least 16 out of 22 were included in the study. Finally, 15 papers were selected (Figure 1).

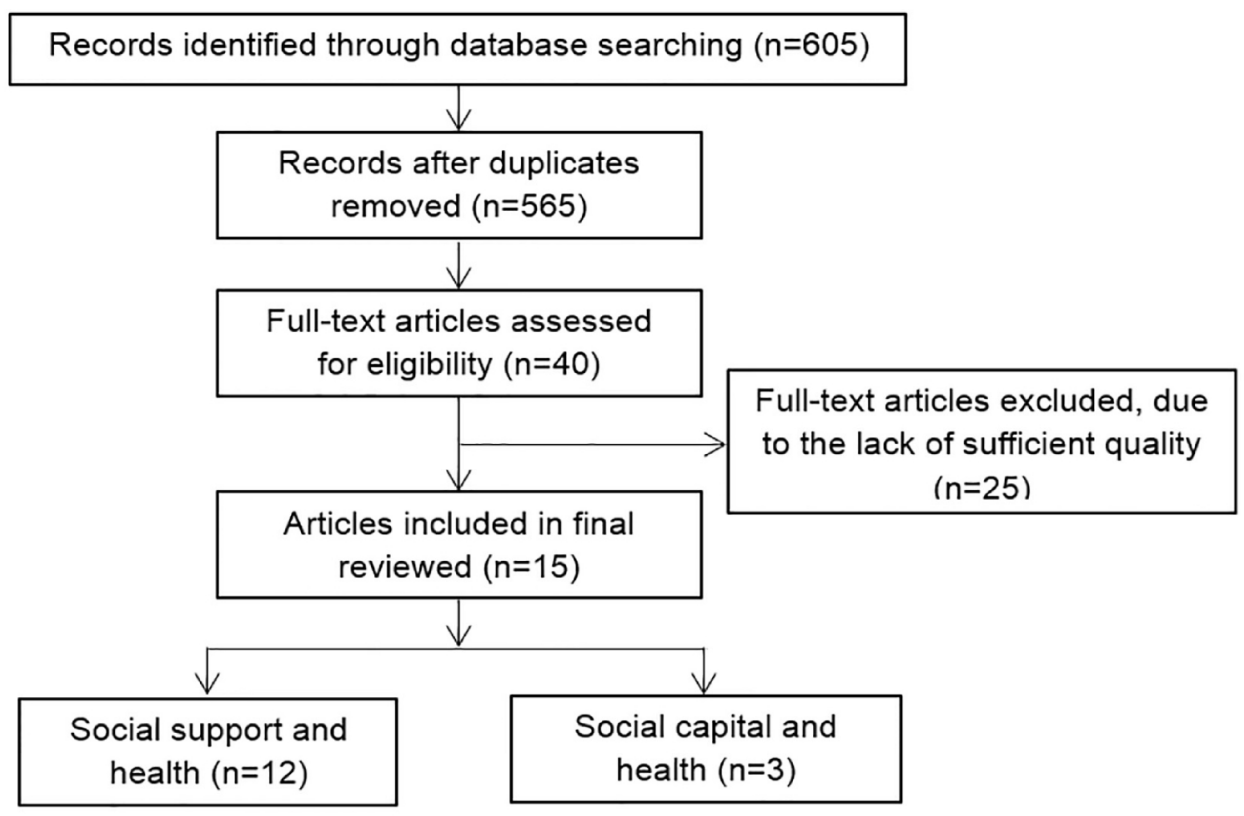

Figure 1: PRISMA flow diagram.

\section{Results}

The present study has investigated the role of social capital and social support on health of female heads of households in different studies. Seven domestic papers and eight international papers were considered for research. The total sample size of the reviewed papers was 12,060 and the method of studying all the papers was crosssectional (descriptive, descriptive-analytical, correlation). Out of 15 papers, two studies examined social capital and mental health $(15,19)$; one study examined social capital and social support as well as mental health $(20)$, five studies examined social support and mental health (21-25), two studies examined social support and quality of life as well as dimensions of health $(26,27)$, two studies examined social support and public health $(28,29)$ and two studies examined social support and social health $(30,31)$. Findings of these papers concluded that there was a significant relationship between social capital and its components (trust, sense of belonging, social participation) with all dimensions of health $(\mathrm{p}<0.001)(15,19,20)$. Furthermore, there was a significant relationship between social support and its dimensions (emotional, instrumental, informational) with general health $(\mathrm{p}<0.05)(22,24,25$, 31). However, among dimensions of social support, instrumental support had a higher correlation coefficient than the other two dimensions of social protection (22). Moreover, the findings showed that presence or absence of a spouse has a significant relationship with social support and social capital $(p<0.001)$, so that female-headed households with no spouse received less social support than female households with spouses $(21,25,29)$. Findings of other studies showed that there was a significant relationship between mental health and social capital in employed and unemployed female-headed households $(\mathrm{p}<0.05)$. In these studies, female-headed households had higher social capital and higher average mental health $(19,28)$. Table 1 summarizes the results. 
Table 1. Studies conducted on the impact of social capital on the health of female heads of households in Iran and across the world

\begin{tabular}{|c|c|c|c|c|}
\hline $\begin{array}{l}\text { Ref. } \\
\text { no. }\end{array}$ & Sitting & $\begin{array}{l}\text { Sampling } \\
\text { method }\end{array}$ & Tool & Findings \\
\hline 15 & $\begin{array}{l}325 \text { female heads of } \\
\text { households supported } \\
\text { by Kerman Welfare } \\
\text { Organization }\end{array}$ & $\begin{array}{l}\text { Simple random } \\
\text { sampling }\end{array}$ & $\begin{array}{l}\text { 1) General Health } \\
\text { Questionnaire, 2) } \\
\text { Researcher- made social } \\
\text { capital questionnaire }\end{array}$ & $\begin{array}{l}\text { The correlation coefficients between trust and } \\
\text { mental health }(-0.357) \text {, sense of belonging and } \\
\text { mental health }(-0.369) \text {, social participation and } \\
\text { mental health }(-0.417) \text {, social support and mental } \\
\text { health }(-0.429) \text { and size of social network and } \\
\text { mental health }(-0.379) \text { were calculated and all } \\
\text { cases were statistically significant }(\mathrm{p}<0.001) \text {. }\end{array}$ \\
\hline 32 & $\begin{array}{l}60 \text { female heads of } \\
\text { households employed } \\
\text { in the Islamic } \\
\text { Revolutionary Guard } \\
\text { Corps in } 7 \text { provinces } \\
\text { (Bushehr, Tehran, } \\
\text { Khorasan, Zanjan, } \\
\text { Kerman and } \\
\text { Kermanshah) }\end{array}$ & $\begin{array}{l}\text { Purposive } \\
\text { sampling }\end{array}$ & $\begin{array}{l}\text { 1) Social support scale - } \\
\text { family scale, 2) Social } \\
\text { support scale-friend } \\
\text { scale, 3) General Health } \\
\text { Questionnaire; GHQ=28 }\end{array}$ & $\begin{array}{l}\text { The correlation coefficients between total score } \\
\text { of social support, depression and mental health } \\
\text { were } 0.498 \text { and } 0.330 \text {, respectively. These } \\
\text { relationships were significant }(\mathrm{p}<0.05) \text {. However, } \\
\text { there was no significant relationship between } \\
\text { social support and general health subscales } \\
\text { (physical health, anxiety and sleep disorders and } \\
\text { social action and performance) ( }>0.05) \text {. }\end{array}$ \\
\hline 19 & $\begin{array}{l}181 \text { female heads of } \\
\text { households supported } \\
\text { by Qom Welfare } \\
\text { Organization }\end{array}$ & $\begin{array}{l}\text { Systematic } \\
\text { sampling }\end{array}$ & $\begin{array}{l}\text { 1) General Health } \\
\text { Questionnaire; GHQ=28, } \\
\text { 2) Keyes Social Health } \\
\text { Questionnaire }\end{array}$ & $\begin{array}{l}\text { Most female heads of households }(39.5 \%) \text { had a } \\
\text { moderate level of social health. Working women } \\
\text { due to their increased social participation and } \\
\text { social cohesion had a higher level of mental } \\
\text { health. }\end{array}$ \\
\hline 26 & $\begin{array}{l}140 \text { married and } \\
\text { single female heads } \\
\text { of households in } \\
\text { Mexico }\end{array}$ & $\begin{array}{l}\text { Stratified } \\
\text { sampling }\end{array}$ & $\begin{array}{l}\text { 1) Beck Depression } \\
\text { Inventory } \\
\text { The World Health } \\
\text { Organization, 2) Quality } \\
\text { of Life Questionnaire, 3) } \\
\text { Social Support } \\
\text { Questionnaire }\end{array}$ & $\begin{array}{l}\text { The means of developing depression in married } \\
\text { and single female heads of households were } 6.66 \\
\text { and } 13.5 \text {, respectively. A significant relationship } \\
\text { was found between social support and developing } \\
\text { depression ( } \mathrm{p}=0.001 \text { ); meaning that single women } \\
\text { were more prone to depression. }\end{array}$ \\
\hline 21 & $\begin{array}{l}2,921 \text { married and } \\
\text { single female heads } \\
\text { of households in } \\
\text { Canada }\end{array}$ & $\begin{array}{l}\text { Simple random } \\
\text { sampling }\end{array}$ & $\begin{array}{l}\text { 1) Demographic } \\
\text { questionnaire, 2) } \\
\text { Interview }\end{array}$ & $\begin{array}{l}\text { There was a significant relationship between } \\
\text { social support and depression in single female } \\
\text { heads of households }(\mathrm{p}<0.05) \text {. The possibility of } \\
\text { their depression was } 50 \% \text { higher than married } \\
\text { women } \\
(95 \% \mathrm{CI}=1.04-2.14, \mathrm{OR}=1.48) \text {. }\end{array}$ \\
\hline 23 & $\begin{array}{l}2,482 \text { married and } \\
\text { single female heads } \\
\text { of households in the } \\
\text { U.S. (Tennessee) }\end{array}$ & $\begin{array}{l}\text { Stratified } \\
\text { sampling }\end{array}$ & Interview & $\begin{array}{l}\text { The frequency of mental health problems was } \\
60.1 \% \text { in single mothers and } 31.2 \% \text { in married } \\
\text { mothers. The frequency of emotional support was } \\
85 \% \text { in married mothers and } 70.8 \% \text { in single } \\
\text { mothers. In terms of participation in social } \\
\text { activities and regarding single women, } 14.3 \% \text { of } \\
\text { them had high levels of participation and } 85.7 \% \\
\text { had low levels of participation. Additionally, } \\
\text { regarding married women, } 26.1 \% \text { of them had } \\
\text { high levels of participation and } 73.9 \% \text { had low } \\
\text { levels of participation. }\end{array}$ \\
\hline 25 & $\begin{array}{l}1,589 \text { married and } \\
\text { single female heads } \\
\text { of households in } \\
\text { Sudan }\end{array}$ & $\begin{array}{l}\text { Random } \\
\text { sampling }\end{array}$ & $\begin{array}{l}\text { 1) Demographic } \\
\text { questionnaire, 2) Social } \\
\text { Support Questionnaire, } \\
\text { 3) (instrumental and } \\
\text { emotional) and } \\
\text { participation }\end{array}$ & $\begin{array}{l}\text { Single women who were heads of households } \\
\text { with lower social capital had lower levels of trust; } \\
2.00 \text {, lower levels of social participation; } 2.44 \text {, } \\
\text { lower levels of instrumental support; } 1.30 \text { and } \\
\text { lower levels of emotional support; } 1.90 \text {, } \\
\text { compared to married women }\end{array}$ \\
\hline 32 & $\begin{array}{l}140 \text { female heads of } \\
\text { households supported } \\
\text { by Imam Khomeini } \\
\text { Relief Committee of } \\
\text { Rudehen }\end{array}$ & $\begin{array}{l}\text { Disproportionate } \\
\text { stratified } \\
\text { sampling }\end{array}$ & $\begin{array}{l}\text { 2) Researcher- made } \\
\text { social support } \\
\text { questionnaire, 2) } \\
\text { Researcher- made social } \\
\text { health questionnaire, } 3 \text { ) } \\
\text { Keyes Social Health }\end{array}$ & $\begin{array}{l}\text { There was a significant positive relationship } \\
\text { between support by nonofficial groups (family, } \\
\text { friends) and social health }(\mathrm{p}<0.001) \text {. However, } \\
\text { there was no significant relationship between } \\
\text { support by official bodies (Imam Khomeini } \\
\text { Relief Committee) and social health ( } \mathrm{p}=0.089 \text { ). }\end{array}$ \\
\hline
\end{tabular}




\begin{tabular}{|c|c|c|c|c|}
\hline & & & Questionnaire & \\
\hline 20 & $\begin{array}{l}220 \text { female heads of } \\
\text { households in an } \\
\text { empowerment Center } \\
\text { in Tehran }\end{array}$ & $\begin{array}{l}\text { Disproportionate } \\
\text { stratified } \\
\text { sampling }\end{array}$ & $\begin{array}{l}\text { Researcher- made } \\
\text { questionnaire }\end{array}$ & $\begin{array}{l}\text { There was a significant negative correlation } \\
\text { between mental health and social capital } \\
(\mathrm{r}=0.496, \mathrm{p}=0.038) \text {. The mean of the mental } \\
\text { health level of working women ( } 33.23 \text { ) was } \\
\text { higher than that of non-working women }(17.20) \text {. }\end{array}$ \\
\hline 22 & $\begin{array}{l}679 \text { female heads of } \\
\text { households in Detroit }\end{array}$ & $\begin{array}{l}\text { Random } \\
\text { sampling }\end{array}$ & In-depth interview & $\begin{array}{l}\text { The standardized regression coefficients for } \\
\text { instrumental social support at moderate and high } \\
\text { levels were }-0.110 \text { and }-0.150 \text { and they were } \\
0.107 \text { and } 0.110 \text { at moderate and high levels for } \\
\text { emotional social support. Between instrumental } \\
\text { and emotional social support, only instrumental } \\
\text { social support was a strong predictor of mental } \\
\text { health. }\end{array}$ \\
\hline 24 & $\begin{array}{l}679 \text { female heads of } \\
\text { households }\end{array}$ & $\begin{array}{l}\text { Simple random } \\
\text { sampling }\end{array}$ & $\begin{array}{l}\text { Short Form of } \\
\text { Depression Inventory } \\
\text { interview }\end{array}$ & $\begin{array}{l}\text { Financial stress }(0.252) \text {, instrumental social } \\
\text { support }(-0.149) \text { and discrimination }(0.107) \text { had } \\
\text { the highest impact on mental health, respectively. } \\
\text { However, there was no statistically significant } \\
\text { relationship between emotional social support, } \\
\text { mental health and depression symptoms ( }>0.01) \text {. }\end{array}$ \\
\hline 29 & $\begin{array}{l}2,034 \text { female heads } \\
\text { of households in } \\
\text { Australia }\end{array}$ & $\begin{array}{l}\text { Random } \\
\text { sampling }\end{array}$ & $\begin{array}{l}\text { 1) Quality of Life } \\
\text { Questionnaire, 2) Social } \\
\text { Support Questionnaire } \\
\text { interview }\end{array}$ & $\begin{array}{l}\text { Unmarried heads of households with low social } \\
\text { support were almost } 5 \text { times more likely to } \\
\text { develop moderate to severe mental health } \\
\text { problems, compared to married women } \\
(\mathrm{OR}=5.46,95 \% \text { CI: } 3.83-7.79) \text {. }\end{array}$ \\
\hline 31 & $\begin{array}{l}340 \text { female heads of } \\
\text { households supported } \\
\text { by Tehran Welfare } \\
\text { Organization }\end{array}$ & $\begin{array}{l}\text { Multi-stage } \\
\text { cluster sampling }\end{array}$ & $\begin{array}{l}\text { 1) Social Health } \\
\text { Questionnaire, 2) } \\
\text { Researcher- made social } \\
\text { support questionnaire }\end{array}$ & $\begin{array}{l}\text { In three dimensions of social support (emotional, } \\
\text { instrumental and informational) and social health, } \\
\text { the Kendall's tau-b correlation coefficients were } \\
\text { obtained as } 0.321,0.352 \text { and } 0.349 \text {, respectively } \\
\text { and in all the cases the relationships were all } \\
\text { statistically significant }(\mathrm{p}<0.01)\end{array}$ \\
\hline 28 & $\begin{array}{l}120 \text { female heads of } \\
\text { households employed } \\
\text { and supported by } \\
\text { Tehran Welfare } \\
\text { Organization }\end{array}$ & $\begin{array}{l}\text { Simple random } \\
\text { sampling }\end{array}$ & $\begin{array}{l}\text { 1) Demographic } \\
\text { questionnaire, 2) The } \\
\text { World Health } \\
\text { Organization Quality of } \\
\text { Life Questionnaire }\end{array}$ & $\begin{array}{l}\text { Working women who were heads of households } \\
\text { and those supported by their families received the } \\
\text { highest social support }(68.8 \% \text { and } 57.5 \%) \text {, } \\
\text { respectively. In both groups, physical and mental } \\
\text { health were significantly related to social support } \\
\text { and communication ( } \mathrm{p}<0.05) \text {. }\end{array}$ \\
\hline 27 & $\begin{array}{l}150 \text { female heads of } \\
\text { households in } \\
\text { Tehran, District } 16\end{array}$ & $\begin{array}{l}\text { Random } \\
\text { sampling }\end{array}$ & $\begin{array}{l}\text { 1) Andrew and Parker's } \\
\text { stressful situations } \\
\text { questionnaire, 2) Wax's } \\
\text { social support scale, 3) } \\
\text { Weir's Quality of Life of } \\
\text { female heads of } \\
\text { households } \\
\text { Questionnaire }\end{array}$ & $\begin{array}{l}\text { The mean score of family support was } 5.86 \pm \\
1.73 \text {; the mean score of support by friends was } \\
4.98 \pm 4.30 \text { and the mean score of support by } \\
\text { others was } 6.12 \pm 1.52 \text {. There was a significant } \\
\text { correlation between social support by family and } \\
\text { quality of life }(r=0.278, p<0.01) \text {; however, there } \\
\text { was no significant correlation between support of } \\
\text { friends and quality of life }(r=0.163, p>0.01) \text {. }\end{array}$ \\
\hline
\end{tabular}

\section{Discussion}

This study has systematically reviewed social capital and social support as well as their relationships with the health of female heads of households. Findings indicated, as female-headed households have higher social capital and social support, their health status will be better, particularly in terms of their social and psychological aspects. In these studies, there were significant relationships between social capital and its main dimensions (social trust, sense of belonging and social participation) and component of mental health $(15,24,26)$. In fact, living in a condition in which individuals feel sense of belonging, trust and acceptance, and receive various aspects of support, creates security and peace of mind. This provides the power to live a quiet life and be able to fight against mental stresses successfully. One of the considerable findings of this study was existence of a significant relationship between family support and mental health (27). Being supported by family and other members is positively correlated with physical and mental health $(33,34)$. Family is considered a powerful source and safe haven against pressures and changes, having a positive impact on stressful situations. In other words, family is the most important and most accessible source of support $(35,36)$. Another finding of this study showed that the mental health score of femaleheads of households with no spouse (divorced, widowed) was at a lower level than the mental health score of those 
who had spouses. Furthermore, they benefited from less social support (21-24, 28). A prevalent cultural belief is easy sexual access to divorced or widowed women. By limiting their social relations, in fact, these women attempt to prevent these kinds of threats, and decline in social relations may result in reduced social support and disrupting their mental health. Results of regression analysis revealed that dimensions of social support (emotional, instrumental and informational support) were among the most important variables in predicting the health of female heads of households and instrumental support played the most important role in this regard (27, 31). Instrumental support refers to financial, objective and actual aid received by one person. This kind of support helps people to meet their daily needs (37). Improvement of living conditions of female heads of households and taking actions to reduce their needs at a time of financial difficulties can increase their health and provide grounds for employment, and creation of sustainable income will promote the level of social participation. According to the theory of Durkheim, the stronger the feeling of intimacy and connection of a person with his family and community is, the less the possibility of endangering his health will be, since this connection protects the person from a destructive agent that is extreme egoism $(38,39)$. Other results showed that the higher the social support from female-heads of households was, the greater their social health would be. Researchers in these studies reported that whether this increased support was performed by official bodies (Imam Khomeini Relief Committee) or nonofficial support groups (family, friends, relatives), social health of female heads of households would increase, in both cases (24, 28, 32). Moreover, they reported that with the increase of support by nonofficial support groups, social health of these women would increase in all dimensions (acceptance, cohesion, participation, prosperity and security). However, support by official bodies' increases their social health only in three dimensions (participation, equality, cohesion) and has no effect on their acceptance, prosperity and security (25). According to Keynesian theory, social health components include social cohesion, social acceptance, social participation, social prosperity and social compliance. Keynes maintained that individuals' quality of life and performance cannot be evaluated without considering social standards $(40,41)$. According to what was mentioned, it can be concluded that there is no law and regulation in nonofficial groups, and relations are intimate and friendly. Individuals can express their opinions freely and it would be helpful in identifying and flourishing their talents. However, in official bodies, due to their laws and regulations, people - especially vulnerable groups- refrain from expressing their ideas and opinions; as a result, sense of security will be less than nonofficial groups and flourishing of talents will not be easy in these supportive groups. The overall results of this systematic review suggest that social determinants of health such as social, mental and financial support, sense of belonging, independence and participation are a set of valuable sources affecting various aspects of social life of people, and higher levels of social capital and social support can improve all aspects of health. Policymakers and planners should improve the quality of life of this vulnerable group based on available tools and resources, and provide needed grounds for formal and informal participation of this group of women through organizing direct and indirect training to support family members, raise their awareness and emphasize the importance of non-governmental organizations. This may create some changes in their level of trust and sense of belonging. Emphasizing formation of local networks to identify and conduct thorough supporting strengthens their self-esteem, importance and efficiency.

\section{Strengths and limitations of the study}

The main strengths of this study are: 1. Summarizing various domestic and foreign studies in the area of social capital and social support and their impact on the health of female heads of household that has not been conducted so far; 2. Increasing knowledge and awareness of researchers and academics on the impact of these social factors and their dimensions on the health of female-heads of households; 3. Raising the fact that further studies and analyses of these factors and their components are needed regarding all aspects of health of female heads of households (physical, mental and social aspects). Limitations of this study include: 1. Lack of access to all papers and unpublished reports; 2. Limited number of papers in the area of social capital and health of female heads of households; 3. Inability to compare and analyze results of different studies due to small number of studies, analyzing few components in different papers and using different sample sizes.

\section{Conclusions}

In summary, the research findings showed social factors such as social capital and social support were effective on the health of female-headed households. Concerning the importance of this subject and the barriers and problems that female-headed households face, it is suggested that appropriate conditions for their presence and active participation in society be provided through culture-building, creating jobs and offering a steady income for their self-sufficiency and empowerment. Performing complementary studies by qualitative and quantitative methods to evaluate all the components of these two social factors and investigating their priority in different dimensions of life of female-headed households, can be an appropriate path for conducting effective interventions. 


\section{Acknowledgments:}

This study is taken from a Ph.D. thesis of reproductive health approved by the Research Council of Shahid Beheshti University of Medical Sciences with Ethics Code of 1395.497. IR-SBMU.PHNM. The authors express their thanks for the cooperation and assistance of the authorities of the faculty, library and computer unit of Shahid Beheshti University of Medical Sciences, Tehran, Iran.

\section{Conflict of Interest:}

There is no conflict of interest to be declared.

\section{Authors' contributions:}

All authors contributed to this project and article equally. All authors read and approved the final manuscript.

\section{References:}

1) Zare H, Mehman-Navazan A. The effect of encouraging the promotion of general self-efficacy and resilience of women heads of households. Journal of Women and Family. 2015; 1: 37-57.

2) Shahriyari E, Saadatmand Z, Fatehi-Zadeh M, Shahnaz M. Survey the training needs of female heads of household who work education. Journal of Women and Society. 2013; 3: 29-45.

3) Herbst CM. Footloose and fancy free? Two decades of single mothers' subjective well-being. Social Service Review. 2012; 86(2): 189-222. doi: 10.1086/666390.

4) Azam-Azade M, Tafteh M. Female-headed households account the obstacles to happiness. Journal of Women and Family Studies. 2016; 2: 33-60.

5) Tavakol M, Maghsoodi S. Social capital and mental health, causal mechanisms and models and interactive. Journal of Social Welfare. 2010; 42: 173-202.

6) Reutter L, Kushner KE. Health equity through action on the social determinants of health': taking up the challenge in nursing. Nursing Inquiry. 2010; 17(3): 269-80. doi: 10.1111/j.1440-1800.2010.00500.x. PMID: 20712665.

7) Marmot M. Closing the health gap in a generation: the work of the Commission on Social Determinants of Health and its recommendations. Global Health Promotion. 2009; 16(1 suppl): 23-7. doi: 10.1177/1757975909103742. PMID: 19477825.

8) Marmot MG, Bell R. Action on health disparities in the United States: commission on social determinants of health. JAMA. 2009; 301(11): 1169-71. doi: 10.1001/jama.2009.363. PMID: 19293419.

9) Riyahi M. How social capital impact on physical and mental health of citizens. Journal of Political Economy. 2011; 286: 198-215.

10) Campbell C, Williams B, Gilgen D. Is social capital a useful conceptual tool for exploring community level influences on HIV infection? An exploratory case study from South Africa. AIDS Care. 2002; 14(1): 41 54. doi: 10.1080/09540120220097928. PMID: 11798404.

11) Misra R, Crist M, Burant CJ. Relationships Among Life Stress, Social Support, Academic Stressors, and Reactions to Stressors of International Students in the United States. International Journal of Stress Management. 2003; 10(2): 137. doi: 10.1037/1072-5245.10.2.137.

12) Writing Committee for the ENRICHD Investigators. Effects of treating depression and low perceived social support on clinical events after myocardial infarction. ACC Current Journal Review. 2003; 12(5): 22-3. doi: 10.1016/j.accreview.2003.08.068.

13) Sarason IG. Social support: Theory, research and applications: Springer Science \& Business Media; 2013.

14) Chant S. Female household headship and the feminisation of poverty: facts, fictions and forward strategies. 2003.

15) Garoosi S, Shabestari S. Study the relationship between social capital and mental health among femaleheaded households in Kerman. Journal of Social Studies. 2011; 5.

16) Mahmud S. Women and the transformation of domestic spaces for income generation in Dhaka bustees. Cities. 2003; 20(5): 321-9. doi: 10.1016/S0264-2751(03)00049-0.

17) Stewart-Withers R. Contesting a Third World development category: Female-headed households in Samoa. Women's Studies International Forum. 2011. Elsevier. doi: 10.1016/j.wsif.2010.11.003.

18) Harpham T, Grant E, Thomas E. Measuring social capital within health surveys: key issues. Health policy and planning. 2002; 17(1): 106-11. doi: 10.1093/heapol/17.1.106. PMID: 11861592.

19) Sam-Aram E, Amini-Yakhdani M. Health status of women heads of household under welfare organization in Qom. Journal promote women Shi. 2009; 6: 133-60.

20) Edrisi F, Hatamvand Z. Evaluate the impact of employment on the quality of life of female-headed households. Journal of social sciences. 2012; 6: 97-127. 
21) Cairney J, Boyle M, Offord DR, Racine Y. Stress, social support and depression in single and married mothers. Social psychiatry and psychiatric epidemiology. 2003; 38(8): 442-9. doi: 10.1007/s00127-0030661-0. PMID: 12910340.

22) Israel BA, Farquhar SA, Schulz AJ, James SA, Parker EA. The relationship between social support, stress, and health among women on Detroit's East Side. Health Education \& Behavior. 2002; 29(3): 342-60. doi: 10.1177/109019810202900306. PMID: 12038743.

23) Kim DS, Jeon GS, Jang SN. Socioeconomic status, social support and self-rated health among lone mothers in South Korea. International journal of public health. 2010; 55(6): 551-9. doi: 10.1007/s00038-010-01699. PMID: 20614228.

24) Schulz AJ, Israel BA, Zenk SN, Parker EA, Lichtenstein R, Shellman-Weir S, et al. Psychosocial stress and social support as mediators of relationships between income, length of residence and depressive symptoms among African American women on Detroit's eastside. Social Science \& Medicine. 2006; 62(2): 510-22. doi: 10.1016/j.socscimed.2005.06.028. PMID: 16081196.

25) Westin M, Westerling R. Social capital and inequality in health between single and couple parents in Sweden. Scandinavian journal of public health. 2007; 35(6): 609-17. doi: 10.1080/14034940701362806. PMID: 17852994.

26) Hernandez RL, Aranda BE, Ramirez MTG. Depression and quality of life for women in single-parent and nuclear families. The Spanish journal of psychology. 2009; 12(01): 171-83. doi: 10.1017/S113874160000158X.

27) Shabanzade A, Zare B, Abadi M, Hatami H, Zahrakar K. The relationship between coping styles and social support, quality Female-headed households living in Tehran. Journal of women and society. 2014; 4: 1-20.

28) Baladchi T, Forozan A, Rafiei H. Quality of life of female-headed households and women who work under welfare organization services. Journal of Social Welfare. 2011; 11: 9-28.

29) Crosier T, Butterworth P, Rodgers B. Mental health problems among single and partnered mothers. Social psychiatry and psychiatric epidemiology. 2007; 42(1): 6-13. doi: 10.1007/s00127-006-0125-4 PMID: 17203237.

30) Hemati E, Mahdavi M, Baghaei-Sarabi A. Effect of social support on the health of women heads of household Journal of Social Research. 2013; 6: 45-62.

31) Hosseini-Haji bakande A, Taghipoor M. The effect of social support on social health of women heads of households. Journal of Social Research. 2010; 7: 139-59.

32) Hamidi F. Relationship between Social support and mental health among female- headed households employed a military university. Journal of Military Psychology. 2010; 1(51-60).

33) Hosseini SJF, Mirdamadi SM, Nejad G, Reza G. Extension and education factors influencing the success of entrepreneurship among rural women in Northern Iran. Research Journal of Biological Sciences. 2009; 4(9): 976-3.

34) Mulvaney-Day NE, Alegria M, Sribney W. Social cohesion, social support, and health among Latinos in the United States. Social science \& medicine. 2007; 64(2): 477-95. doi: 10.1016/j.socscimed.2006.08.030. PMID: 17049701.

35) Dayapoglu N, Tan M. Quality of life in stroke patients. Neurology India. 2010; 58(5): 697. doi: 10.4103/0028-3886.72165.

36) Vazquez I, Valderrabano F, Fort J, Jofre R, Lopez-Gomez JM, Moreno F, et al. Psychosocial factors and health-related quality of life in hemodialysis patients. Quality of Life Research. 2005; 14(1): 179-90. PMID: 15789952.

37) Drentea P, Clay OJ, Roth DL, Mittelman MS. Predictors of improvement in social support: Five-year effects of a structured intervention for caregivers of spouses with Alzheimer's disease. Social science \& medicine. 2006; 63(4): 957-67. dio: 10.1016/j.socscimed.2006.02.020. PMID: 16616406.

38) Hemati R, Rahimi-Aliabadi A. Investigate the relationship between social support and mental health. Social science studies. 2014; 10: 105-19.

39) Rimaz S, Mohammad K, Dastoorpoor M, Jamshidi E, Majdzadeh R. Investigation of relationship between social capital and quality of life in multiple sclerosis patients. Global journal of health science. 2014; 6(6): 261. doi: 10.5539/gjhs.v6n6p261. PMID: 25363095.

40) Afkhe SA, Sam-Aram M. The public health impact on job satisfaction. Journal of Social Welfare and Development Planning. 2010; 3: 1-30.

41) Keyes CL. The mental health continuum: From languishing to flourishing in life. Journal of health and social behavior. 2002: 207-22. doi: 10.2307/3090197. PMID: 12096700. 